\title{
A noite explode nas cidades. Três hipóteses sobre Vinagre: uma antologia de poetas neobarracos
}

Gustavo Silveira Ribeiro

UFMG

Para Jaime, Vinícius, Nicola

\begin{abstract}
Resumo
O artigo lê o livro eletrônico Vinagre: uma antologia de poetas neobarracos, organizado por Fabiano Calixto e Pedro Tostes, buscando pensar a partir dele as manifestações de rua de Junho de 2013, motivo explícito do livro e até agora poucas vezes abordado a partir de seus desdobramentos estéticos e representacionais na cultura. Tomando a internet como ponto de encontro, produção e agenciamento da criação poética e da gestação de forças políticas de resistência, o artigo propõe três hipóteses específicas sobre Vinagre, a saber: a relação do livro com uma guinada política que vinha (e vem) se processando no cenário da poesia brasileira contemporânea; a existência de uma homologia formal entre a estrutura da coletânea e os próprios eventos de Junho; a centralidade, no conjunto heterogêneo dos poemas, da violência policial e seus efeitos perversos.

Palavras-chave: Poesia brasileira contemporânea; Política; Jornadas de Junho; Violência policial.
\end{abstract}

\section{Resumen}

El artículo lee el libro electrónico Vinagre: uma antologia de poetas neobarracos, organizado por Fabiano Calixto y Pedro Tostes, buscando pensar a partir de ese libro las manifestaciones de Junio de 2013, motivo explícito hasta hoy poco abordado a partir de sus desarrollos estéticos y representacionales en la cultura. Pensando internet como punto de encuentro, producción y agenciamiento de la creación poética y de la gestación de fuerzas políticas de resistencia, el artículo propone tres hipótesis sobre Vinagre, a saber: la relación del libro con un giño político que se procesa en el escenario de la poesía brasileña contemporánea; la existencia de una homología formal entre la estructura de la antología y los mismos eventos de Junio; la centralidad, en el conjunto heterogéneo de los poemas, de la violencia policial y de sus efectos perversos.

Palabras clave: Poesía brasileña contemporánea; Política; Jornadas de Junio; Violencia policial. 


\section{Uma poética do atrito}

Publicado em fins de junho de 2013, no centro dos acontecimentos políticos que abalaram o Brasil naquele mês, o livro eletrônico Vinagre: uma antologia de poetas neobarracos, organizado por Fabiano Calixto e Pedro Tostes, ainda é, passados já dois anos, a expressão artística mais imediata e ao mesmo tempo mais significativa daquele contexto, surgindo como uma consequência direta, uma espécie de instantâneo tomado no calor da hora, pleno de espontaneidade e desorganização, nascido sem planejamento prévio, de modo algo semelhante, quem sabe, ao das próprias manifestações que inundaram as cidades brasileiras. Atuando como um elaborado arquivo dos afetos e das tensões, das violências, imagens e esperanças daqueles dias de fúria e expectativa, os poemas reunidos em Vinagre, sob essa perspectiva, vêm se somar - guardadas, é verdade, as muitas e importantes distinções existentes - aos milhares de vídeos e fotos pessoais feitos durante os protestos, cada um deles constituindo pequenos fragmentos de um evento que, pela sua natureza movente e coletiva, permanece não-reconstituível em sua totalidade. Os próprios organizadores do volume, e também os seus primeiros e raros comentadores, procuraram ressaltar a urgência e a rapidez do material, dado à luz, em sua primeira edição, num intervalo de pouquíssimos dias desde a eclosão da violência e dos protestos massivos. Por tudo isso, talvez, e também pela irregularidade de algumas das composições apresentadas no livro (parte delas peças mais simples de agitação política ou comoção individual diante das demandas do momento), Vinagre não tenha recebido atenção crítica à sua altura, lida tão somente como poesia de circunstância - documento político de alguma relevância, mas nada além disso. Contrariando esse diagnóstico, por outro lado, gostaria de propor, como hipótese de trabalho, outra leitura, observando de modo diverso a sequência de acontecimentos e eventos culturais que levou até o surgimento de Vinagre. Longe de ser fruto das circunstâncias ou de paixões fortuitas, o livro é expressão (quem sabe mesmo a consolidação) de uma tendência específica no cenário da poesia brasileira contemporânea.

Nas diversas avaliações feitas sobre as manifestações, tanto no momento em que elas ainda aconteciam e seu destino era incerto, quanto naquelas que vêm sendo realizadas hoje, sempre costuma aparecer a hipótese de que os eventos de junho/2013 foram, como se costuma dizer, um raio em céu azul, um fenômeno inesperado e imprevisível sem qualquer relação causal com as lutas sociais e os movimentos organizados do país. Ainda que não seja essa a única leitura do período, nem mesmo a sua compreensão hegemônica, é interessante observar 
como essa tese reaparece sem cessar, impondo a muitos analistas a descontextualização das múltiplas origens dos protestos e pulverizando, desse modo, os seus desdobramentos e legados, tornando-os irrelevantes ou facilmente apropriáveis por setores conservadores da sociedade, uma vez que a intempestividade do que ocorreu seria índice do caráter apenas reativo de todo o processo. Se procuro expor algumas ideias sobre a poesia surgida em torno das manifestações, recordar certos aspectos da disputa discursiva que cerca os eventos de Junho talvez não seja de todo contraproducente, na medida em que se identifica na recepção de Vinagre (nas poucas leituras ensaiadas e principalmente nas não-leituras, no silêncio que o cercou) - guardadas, é claro, as dimensões da questão em pauta - alguns dos mesmos problemas e disputas. A partir do momento que a antologia organizada por Calixto e Tostes é vista como produção voluntarista, reativa e panfletária (posto que ligada a uma circunstância específica e limitadora), a observação e o entendimento das suas potencialidades estéticas e críticas decaem inevitavelmente. Se, além disso, se perde a perspectiva histórica e cultural que viu surgir o livro, desprendendo-o dos elos que o mantém atado não só aos acontecimentos dramáticos de dois anos atrás, mas principalmente ao notável contorno político que a poesia dos últimos anos no Brasil vem assumindo, a compreensão de Vinagre permanecerá sempre incompleta e deficitária, e aquilo que o livro realmente têm de fortuito e casuístico tenderá a predominar, obscurecendo o seu peso e relevância.

Para afirmar direta e claramente: Vinagre: uma antologia de poetas neobarracos não deve ser lido como acontecimento isolado na cena poética contemporânea: o trabalho se liga a uma sequência articulável de livros e poemas que, no curso da última década, construíram e partilharam textos que são atravessados pela imaginação política que, de modo semelhante, percorre também a antologia. Percebida por parcela razoável da crítica, dentre a qual se destacam, entre outros, os esforços de Vera Lins (autora dos importantes ensaios "Poesia e tempos sombrios: alguma poesia hoje" e "O poema em tempos de barbárie"), João Camillo Penna ("A violência da poesia" e "Poética da vítima", escritos na mesma época, em torno a um mesmo argumento), Eduardo Sterzi ("Terra devastada: persistências de uma imagem", principalmente) e Fábio Weintraub ("Poética do desabrigo: imagens do habitar em crise na poesia brasileira contemporânea"), a retomada de uma dicção política no universo da poesia brasileira do presente responde, acredito, a múltiplos fatores, em meio aos quais devem ser considerados a) o acirramento das disputas ideológicas em torno do lugar e do papel da arte num mundo em flagrante processo de desagregação, cujas estruturas tradicionais de poder e representação política se desfazem com a mesma velocidade com que crescem a desigualdade e a catástrofe 
ecológica, realidade de que o país certamente é parte e b) uma leitura crítica da história recente da própria poesia no Brasil, dedicada, na década anterior - e é sempre preciso ter em mente os casos de exceção e desvio - à consideração prioritária de outros debates, quase todos voltados a filiações estéticas e a dilemas da tradição moderna da cultura brasileira. A guinada política a que me refiro, nesse sentido, não é ela mesma uma ação reflexa ou uma invenção geracional - posto que a poesia política sempre foi importante entre nós, seja em contextos específicos como o período em torno da Ditadura Civil-Militar (1964-1985), seja na obra de nomes decisivos como Carlos Drummond de Andrade, Haroldo de Campos, Armando Freitas Filho, Francisco Alvim ou Age de Carvalho - isto é, ela não se define apenas como reação artística a um contexto histórico-social contraditório e particular, mas vem responder também a dinâmicas internas da cena literária, que se somam, é certo, à percepção individual dos seus principais poetas, das leituras que fazem e das tradições que procuram atualizar e reinventar com os seus trabalhos. É dentro desse cenário multifacetado que um projeto amplo como Vinagre deve ser assimilado, uma vez que sua natureza híbrida, voltada para a história política e para a série literária e cultural, aponta nessa direção.

Se quisesse enumerar algumas das características e temas, parte de uma lista sempre parcial e inconclusa, dessa energia política comum, levada à frente com brilhantismo por uma série importante de autores do presente e continuada, pouco importa se de modo consciente e desejado, pelos conhecidos e desconhecidos poetas de Vinagre, resultaria o que segue: o diagnóstico terrível de um mal-estar amplo, ligado ao tempo presente e à sensação de esgotamento que dele parece emanar; a representação problemática da condição de estrangeiro e migrante; a onipresença da violência, seja a que se liga à desigualdade social, seja, em especial, aquela praticada ontem e hoje por agentes do Estado; a busca, da e na poesia, pela experiência e pela beleza, ambas entendidas como resíduo e sobrevivência quase clandestina no mundo contemporâneo. Em livros como Planos de fuga e outros poemas (2005), de Tarso de Melo - aqui escolhido, com a arbitrariedade que caracteriza toda seleção desse tipo, como o primeiro da série que quero destacar -; Sanguínea, de Fabiano Calixto, e Baque, de Fábio Weintraub, ambos de 2007; Cinco lugares da fúria (2008), de Pádua Fernandes; Monodrama (2009), de Carlito Azevedo; Aleijão (2009), de Eduardo Sterzi e Um útero é do tamanho de um punho (2012), de Angélica Freitas, para citar apenas uns poucos autores, é possível perceber como foram crescendo e se afirmando as muitas tonalidades que a poesia política tem no Brasil hoje. Lembro alguns exemplos: os poemas em prosa de Planos de fuga, que reescrevem versos e imagens do alto modernismo brasileiro (Drummond e Bandeira principalmente), 
dando a eles a vibração e o incômodo das tensões contemporâneas, dão bem a medida da questão. $\mathrm{O}$ que se tem aqui é a crônica do horror cotidiano, da vida nas cidades transformada em guerra civil:

\begin{abstract}
a cada dia um novo bicho; já um repleto bestiário desde aquele que, no lixo, na imundície do pátio, comida entre os detritos. Um: morto, a golpes de canivete; invadiu o semáforo em que outro prestava iguais serviços. Dois: ainda vivo, cruza o gelo dos dias e, pelo álcool, o hipermercado. Três: morto, veste as folhas de jornal, tinge-as, fede enquanto a viatura não chega; ninguém viu nada. ${ }^{1}$
\end{abstract}

Do mesmo modo, mas num trabalho distinto com a linguagem e a forma, Eduardo Sterzi vai propor seu "Jogo", no qual a cena tristemente comum (no país) da morte a pancadas - um linchamento, quem sabe? -, vai ser apresentada desde dentro, numa perspectiva sutil que é, ao mesmo tempo, extremamente subjetiva, posto que interna e particular, colada à experiência da vítima, mas igualmente social e impessoal, apresentada como cena para a qual têm de concorrer, obrigatoriamente, outros agentes, depositários de uma força cega, eivada de autoritarismo e violência punitiva:

\author{
a lâmina do sono \\ suja do próprio sangue \\ do sangue de outro \\ aos poucos vai até \\ afogando no sono \\ que desce pela garganta \\ vem dos ouvidos \\ só pensa \\ proteger os olhos \\ proteger a nuca \\ proteger a têmpora \\ parece que sorri \\ à espera do último \\ que não vem \\ $[\ldots]^{2}$
}

A reivindicação da centralidade e da potência do corpo, compreendido como campo de batalha fundamental nos choques contra o poder (econômico, biopolítico, religioso e cultural), também se faz presente como ponto de partida decisivo para muitas das poéticas que se desenvolvem agora, várias delas repercutindo diretamente nos textos que compõem Vinagre. A poesia de Angélica Freitas me parece a elas endereçada, propondo aguda reflexão, o mais das vezes pela via do humor e da paródia dos discursos do establishment, sobre questões como o aborto, a sexualização impositiva das mulheres e o feminicídio, temas que atravessaram, misturando-se às lutas econômicas e anticapitalistas, de ponta a ponta as manifestações:
1. MELO, Tarso de. Planos de fuga e outros poemas, 2005, p. 15.

2. STERZI, Eduardo. Aleijão, 2009, p. 98. 
3. FREITAS, Angélica. Um útero é do tamanho de um punho, 2012, p. 61.

4. Cf. DERRIDA, Jacques. De que amanhã..., 2004.

5. CALIXTO, F. \& TOSTES, P. Vinagre, 2013, p. 53.

6. Ibidem, p. 145.

\author{
um útero é do tamanho de um punho \\ num útero cabem capelas \\ cabem bancos hóstias crucifixos \\ cabem padres de pau murcho \\ cabem freiras de seios quietos \\ cabem as senhoras católicas \\ que não usam contraceptivos \\ cabem as senhoras católicas \\ militando diante das clínicas \\ às $6 \mathrm{~h}$ na cidade do méxico \\ e cabem seus maridos \\ em casa dormindo \\ cabem cabem \\ sim cabem \\ e depois vão \\ comprar pão \\ $[\ldots]^{3}$
}

Arregimentados com a urgência que cumpria ter naqueles dias emergenciais, de levante e incerteza poucas vezes vistos na história do país, os poemas de Vinagre relêem e continuam uma tendência recente da lírica brasileira, sendo sua imagem concentrada. Sem deixar de reconhecer a importância do caráter intempestivo de muitos daqueles textos, e mesmo da condição de resposta (em sentido forte, derridiano, segundo o qual responder a um evento é tornar-se responsável por ele, acolhendo o seu chamado e tornando-o um imperativo e uma escolha ${ }^{4}$ que vários assumem), seria impossível não notar nos versos de Diego Vinhas “a voz-rádio-am/ narra outro/ episódio de lixo/ especulado, lua/ cortada por sirenes, / eco anônimo/que abafado/golpeia e perfura/ a apatia do prédio,/ a veia cava" ${ }^{5}$ ou Rodrigo Lobo Damasceno

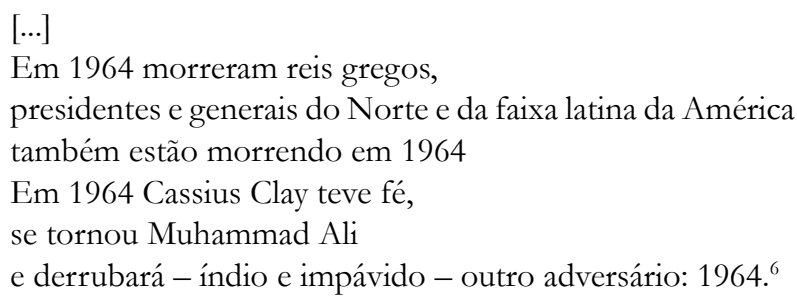

a mesma complexidade no entrelaçamento de sofisticação formal e impulso participante que se nota facilmente no conjunto de poetas que, na última década, lograram repropor a dimensão política da lírica brasileira. Os poemas recolhidos em Vinagre, é certo, podem ser lidos sem essa moldura historiográfica; algo de sua força, entretanto, se aquieta e dispersa, se assim for.

\section{Rua, começo do mundo}

Mais do que os óbvios e obrigatórios laços contextuais e temáticos que os aproximam, há entre Vinagre e as manifestações 
de Junho uma relação que se poderia chamar estrutural, um tipo de homologia complexa em que não há apenas espelhamento e equivalência, mas igualmente refração, processos de repetição em diferença. Muitos dos elementos que definiram os protestos - sem os limitar ou esgotar realmente, na medida em que, para dizer com Idelber Avelar, Junho permanece ainda, pelo menos em parte, um enigma ${ }^{7}$ - atravessam também, dando a ele sentido e organicidade, o corpo dinâmico da antologia. A poesia política que ali se organiza possui, e essa é uma afirmação de caráter geral, válida do mesmo modo para outras obras e configurações estéticas, o caráter intempestivo, o elemento anacrônico e disruptivo que marcou os protestos. Eles, assim como a poesia (o verdadeiro trabalho poético), são e só podem ser événement, acontecimento singular, fenômeno fora da ordem, no duplo sentido - cronológico e jurídico - do termo; só podem existir como surpresa e antecipação de um conteúdo ainda impensado, latente, mas não conhecido ou mensurável em toda a sua extensão. Ambas são, talvez, os "Alpes submersos na Austrália", imensos e invisíveis, de cuja presença avassaladora fala Júlia de Carvalho Hansen em "Os guardas dormem na floresta":

\author{
De repente manifesto \\ a gente \\ vai se voltar a um outro escalão: \\ montanha, névoa, marulho, o metrô que é o nosso trovão \\ então você acha que os cantos estão mudando de lugar \\ mas é a gente que vê os homens constrangidos da cidade \\ e tenta: enseada sobre asfalto, essa manhã, \\ porque tudo que é, é o nosso \\ estou no ponto pro Jardim da Glória, lendo a realidade \\ cientistas descobrem Alpes submersos na Austrália \\ na contracapa um coração selvagem pela metade \\ o cheiro de perto do sal um potro de pulmões novos \\ e o mar, ah oceano cavalgadura, \\ absolutamente estrangeiro a mim nesse interior sem tamanho \\ eu juro que esse túnel não acaba \\ estão nos levando a um lugar de verdade.
}

Nisto, e também em outros aspectos, poesia e política se aproximam: ambas são evento, ação, um tipo específico de poiesis que não admite a aplicação de fórmulas e a previsão dos resultados. Trata-se de um fazer que se limita com o risco e a invenção, e no qual se aposta tudo. De outro modo, não se trataria de fato
7. Cf. AVELAR, Idelber. Crônicas do estado de exceção, 2014.

8. CALIXTO, F. \& TOSTES, P. Vinagre, 2013, p. 98. 
9. Não é outra coisa o que propõe Jacques Derrida, num texto-limite dos anos 1990: "uma forma absolutamente única, um evento cuja intangível singularidade já não separasse a idealidade, o sentido ideal, como se diz, do corpo da letra. No desejo dessa inseparação absoluta, do não-absoluto absoluto, respiras a origem do poético". DERRIDA, Jacques. Che cos'è la poesia?, 2003, p. 8.

10. Refiro-me às palavras citadas de Alexandre Nodari: "Negociação de engravatados em gabinete é polícia (administração, gerência). Política é outra coisa, é gente OCUPANDO a rua”. CALIXTO, F. \& TOSTES, P. Vinagre, 2013, p. 6.

11. CALIXTO, Fabiano apud. MASSUELA, Amanda. Vinagre e poesia, 2013.

12. STERZI, Eduardo apud. FREITAS, Guilherme. Ação e invenção, 2013.

13. Cf. JUDENSNAIDER, Elena. Vinte centavos: a luta contra o aumento, 2013.

14. HARVEY, David. Cidades rebeldes, 2014, p. 27-66. de política: mas sim de administração de coisas, negociações de bastidores que apenas rearranjam as forças em jogo, cálculo no qual todos os movimentos já estão dados desde o início, e onde não há espaço algum para a transformação e o novo. De outro modo, não se trataria de fato de poesia: mas sim de poéticas previamente postas, bem ou mal executadas; repetição não-diferenciada de fórmulas e efeitos estéticos codificados, fechada absolutamente para a alteridade radical, para a solidão essencial do poema ${ }^{9}$. É pensando nessas questões que alguns dos organizadores e participantes da antologia puderam afirmar, na esteira de uma das epígrafes postas no trabalho ${ }^{10}$, que "a poesia é algo muito próximo do berro"11 ou "todo bom poema tem um quê de quebra-quebra, todo poeta é um pouco vândalo" 12 . A relação que se observa, assim, entre Vinagre e as marchas populares se dá sob o signo do intempestivo: a irrupção das vozes e corpos nas ruas, o exercício efetivo e inesperado da política - o assalto aos céus, na célebre formulação de Marx - tem a mesma força de choque e ruptura que têm alguns dos poemas ali colocados (e também a própria antologia, entendida como ação imediata de resposta ao acontecimento que se desdobrava na arena pública).

A incrível dispersão de vozes e o caráter multitudinário e algo incongruente que caracterizou os protestos brasileiros irão, por sua vez, encontrar o seu termo de comparação no plano geral de Vinagre. Ponto de convergência de reivindicações variadas e muitas vezes contraditórias entre si, as manifestações de Junho foram na verdade um conjunto de ações não-coordenadas, na sua maioria, que ligavam grupos e demandas políticas muito distintas, ocasionalmente reunidos em torno de bandeiras comuns, geralmente questões amplas e vagas o suficiente para poderem ser - como foram tantas vezes - apropriadas por discursos e organizações políticas antagônicas. A revogação do aumento das tarifas de transporte, por exemplo, reivindicação econômica que deflagrou, primeiro em São Paulo e logo no restante do país, o processo de lutas que está no início da narrativa dos protestos ${ }^{13}$, foi assimilada por diversos grupos, nem todos ligados efetivamente aos movimentos tradicionalmente identificados àquela demanda histórica específica: aos estudantes, desempregados e moradores da periferia, por décadas protagonistas das batalhas pelo rebaixamento dos preços, somaram-se ondas intermináveis de jovens de classe média, profissionais em início de carreira ou moradores de bairros privilegiados da cidade, gente que não depende do transporte público mas que projetava ali, na fissura aberta pelo aumento abusivo, um espaço para questionar o problema amplo da mobilidade urbana (problema que, conforme propôs David Harvey, ${ }^{14}$ está no centro das recentes explosões de revolta em grandes cidades, posto que a especulação imobiliária, o apartheid não formalizado, mas bastante efetivo, que segrega e militariza as zonas periféricas das cidades, são algumas 
das faces mais duras, hoje, da injustiça social e da exploração capitalista), reivindicando ciclovias, corredores de ônibus ou até exigindo contraditoriamente, como em alguns casos, baixa geral dos impostos que incidem sobre carros de passeio. A amplitude da insatisfação, como se vê, era grande e ambígua. O mesmo fenômeno pôde ser igualmente percebido nas palavras-de-ordem contra a Copa do Mundo do Brasil, por mais verbas para Educação e Saúde, pelo fim da corrupção no aparato do Estado: para alguns, tratava-se de propor e defender, a partir desses pontos de aglutinação, pautas críticas de caráter urgente, que colocassem em xeque os fundamentos da desigualdade social e do viés autoritário da vida pública brasileira; para outros, entretanto (e todos se reuniam e às vezes confundiam no dia a dia das manifestações), a hora era de exigir privilégios, condenar programas sociais de distribuição de renda, enaltecer o papel histórico de instituições sabidamente violentas e discricionárias como a Polícia Militar (PM) e o Batalhão de Operações Especiais (BOPE).

Pois bem, algo dessa dispersão e incongruência habita $V i$ nagre: uma antologia de poetas neobarracos. Parte da diversidade irredutível que constituiu a multidão que tomou as ruas do país se faz presente no livro, dada a sua própria condição de espaço de convergência para autores e textos distintos, muitos dos quais escritos em tempos e circunstâncias particulares, apesar de todos procurarem apontar para os eventos daquela época. A mais importante das grandes questões a atravessá-lo - fio comum com que vão sendo tecidos os mais diferentes poemas - é a violência e a repressão policial, estopim dos primeiros protestos massivos e da elaboração da antologia. Sobre a violência, entretanto, trataremos com mais calma na terceira parte deste ensaio. Por ora, valerá perceber que, se não estão presentes no livro a mesma confusão ideológica dos atos, se não é importante o elemento político da disputa por protagonismo e direção que se verificou nas ruas brasileiras, em Vinagre o desnivelamento dos textos que o compõem, bem como a ausência de um projeto qualquer que procure organiza-los como um livro de partes bem definidas dão a medida do elemento dispersivo que o singulariza. A plataforma em que foram reunidos e divulgados oferece-se igualmente como matéria para reflexão: foi a internet um dos palcos decisivos das manifestações, uma vez que a horizontalidade das marchas e assembleias, a velocidade e mobilidade com que eram convocados e avaliados não deixa de ser semelhante (e não apenas pelo meio digital, é preciso esclarecer desde já), com o processo de concepção e execução de Vinagre. A rapidez, o alcance e a diversidade de vozes que formam a antologia só foi possível pelas trocas virtuais, pelas redes colaborativas surgidas no correr dos acontecimentos, muitas delas forjadas para e nas manifestações. A estrutura descentralizada e 
15. CALIXTO, F. \& TOSTES, P. Vinagre, 2013, p. 144.

16. Cf. NEGRI, Antonio. Pour une définition ontologique de la multitude, 2002. Cf. HARDT, Michael \& NEGRI, Antonio. A Multidão contra o Império, 2005. folicular, desdobrável em muitos sentidos, é visível, ainda que com diferenças importantes, nos dois contextos. As metáforas muito recorrentes da rede e da corrente, parte do vocabulário básico daqueles dias, lançam luz importante no horizonte comum, mas jamais idêntico, dos protestos e da antologia.

Um poema como "Inverno brasileiro", de Rodrigo Garcia Lopes, traz uma imagem-base (refratada numa série cumulativa) que o traduz perfeitamente, além de acrescentar a ele (o elemento dispersivo) outros sentidos:

A Multidão é uma serpente de cem mil olhos bocas peles e [vozes

A Multidão aparece em segundas nubladas Ninguém segue nem segura a Multidão, ela nos leva A Multidão avança entre os prédios públicos e praças e [condomínios como uma grande onda

A Multidão murmura sentidos atávicos, despista seus [perseguidores, se dispersa, se divide, arrebata mais furiosos avatares e se reencontra

A Multidão atordoa a mídia, perplexa especialistas, confunde [extraterrestres,

A Multidão é a soma das individualidades cuspindo desejos \& [desapontamentos,

Elétrica Pulsante em Movimento a Multidão tem a vibração de [mil megatons

A Multidão é jovem é velha é sexy é solitária é firme é serena $[\cdots]^{15}$

No texto não se encontra o elogio heroico da multidão, como em Antonio $\mathrm{Negri}^{16}$, que reconhece nela o agente fundamental e indiviso da História. A ambiguidade da imagem inicial, a "serpente de mil olhos bocas peles e vozes", com o aceno ao grotesco que contém, esvazia a mitificação às vezes ingênua da multidão, ainda que reconheça a sua força peremptória e desestabilizadora. O que importa de fato é a caracterização múltipla, nunca completa, da multidão, retrato móvel de um agenciamento formado pela soma (sempre desigual e heterogênea) de "individualidades, desejos \& desapontamentos". O vetor de sua aproximação é o da precariedade e da aliança provisória. Tal como parece ser o caso dos poemas de Vinagre. Vinculados a poéticas às vezes incompatíveis entre si, que atendem a solicitações e impulsos estéticos discrepantes, boa parte daqueles textos só convive com os demais num conjunto que aspira à obra porque entre eles se formou uma estranha solidariedade, um pertencimento que remonta mais ao evento que os reuniu (os protestos, a empreitada coletiva da antologia, a revolta diante da intensa repressão) do que a qualquer traço de unidade estilístico, formal ou mesmo ideológico. Há exceções, é certo, e muitos poemas estão atados por laços profundos de experimentação linguística ou interrogação filosófica, marcas mais ou menos 
evidentes de um percurso geracional; entretanto, é o aspecto multitudinário e poliédrico o que prevalece, e é daí que Vinagre tira a sua força e conhece também os seus limites.

Compare-se, por exemplo, poemas como "Lembrete", de Adriano Scandolara - seu tom algo brechtiano, suas elipses com outro como "O dia do povo", de Domenico A. Coiro, de retórica caudalosa, cumulativa, feita de cacos de discursos alheios e vivas à vitória; pouco terão em comum, ainda que circundem o mesmo fato. Do mesmo modo, leitura contrastiva entre o já citado "Índio (Poema-Wikipédia)", de Rodrigo Lobo Damasceno, e "Balada a favor das últimas manifestações", de Fabrício Corsaletti, revela como ambos leem de modo muito diferente o chamado emitido pelas manifestações, optando por operações poéticas de carnadura e eficácia bastante diferente. Enquanto o primeiro escolhe escavar o substrato histórico das violências que se multiplicavam naqueles dias de repressão, recuperando a memória da ditadura e notando criticamente sua longa duração entre nós - o ano 1964, "outro adversário", ainda precisa ser derrubado, afinal - no segundo, Corsaletti prefere recorrer a uma forma popular e musical (a balada), para com ela compor uma canção de homenagem, estritamente atenta aos eventos específicos das passeatas, e por isso mesmo mais próximo do circunstancial:

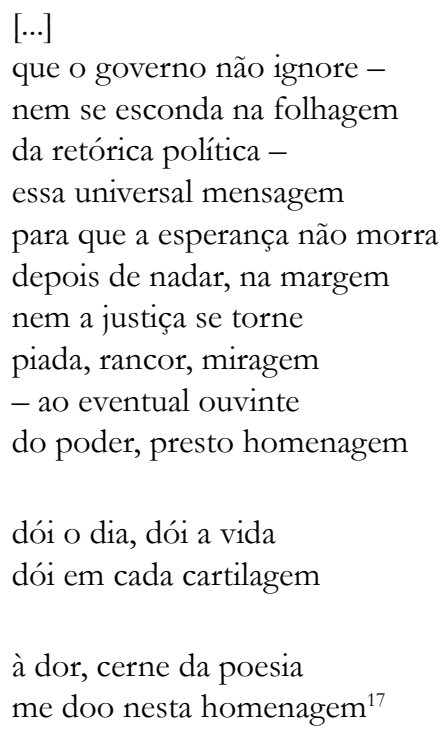

Comunidade de desiguais, a antologia proposta por Vinagre apresenta arestas e incompatibilidades comparáveis àquelas apresentadas pelos protestos de Junho, especialmente quando vistos a certa distância, como um conjunto finito e reconhecível de ações. O calor dos acontecimentos, os mil acidentes que direcionaram muitas das escolhas do que ocorreu na rua também cobraram seu preço na fatura de vários poemas e do próprio projeto como um todo. Apesar disso, a mesma força imprevista,
17. CALIXTO, F. \& TOSTES, P. Vinagre, 2013, p. 72. 
18. Cf. ZIZEK, Slavoj. Problemas no paraiso, 2013, p. 103-111.

19. Cf. NOBRE, Marcos. Choque de democracia - razões da revolta, 2013. a mesma inesgotabilidade das movimentações (dado já destacado por alguns comentaristas, entre eles Slavoj Zizek ${ }^{18}$ e Marcos Nobre ${ }^{19}$ ) percorre também a coletânea. O cenário poético do país se alterou depois dela, como a cena geral das lutas políticas brasileiras não é mais a mesma, para o bem e para o mal, depois de Junho.

\section{Poesia. Polícia. Pensamento}

Imagem mais frequente e perturbadora nos poemas que constituem Vinagre, a violência policial é, sem dúvida, a questão fundamental da antologia, a cena originária de tantos de seus poemas, o centro aglutinador, enfim, em torno do qual textos e autores tão diferentes (a segunda edição traz 154 poetas) vão se reunir e conspirar. Desde o título da antologia, esse é um fato evidente. Vinagre colhe seu nome no absurdo da repressão policial: usado por muitos manifestantes como proteção contra os efeitos do gás lacrimogêneo fartamente usado pelas forças do Estado, o vinagre tornou-se um dos símbolos dos protestos porque muitos ativistas, país afora, foram detidos simplesmente por trazer consigo garrafas - de plástico - do produto. O porte de vinagre passou a ser a contraprova definitiva do vandalismo, justificação oficial da pancadaria e das detenções arbitrárias, índice mais que eloquente do estado em que se encontram os direitos civis no Brasil. Designada por alguns como a 'Revolta do Vinagre', as rebeliões de Junho estiveram fortemente atadas à ação criminosa da polícia; era de se esperar que a poesia surgida nesse contexto tivesse também fortes laços com a violência - seja a dos agressores, seja aquela deflagrada, como forma de defesa e reação, pelos manifestantes. A ressignificação do objeto/produto comum, ora maldito (o vinagre) e do qualificativo degradante que o acompanhava (vândalo) é o primeiro e coletivo ato poético da antologia: ao assumirem a si mesmos como vândalos e o vinagre como ícone de desobediência e desafio, os autores transformam o pejorativo em qualidade, o absurdo em força criativa; fazem de palavras gastas e sobredeterminadas vocábulos de beleza e contestação.

A hipótese proposta aqui é a de que Vinagre: uma antologia de poetas neobarracos pode ser lido como uma radiografia das violências discursivas e físicas que atravessaram as manifestações, mas uma radiografia de tipo muito específico, melhor definida, talvez, pelo seguinte jogo de palavras (que almeja ser equação): as formas da violência e as violências da forma. Explica-se: o livro cataloga e expõe as múltiplas maneiras por que se perpetrou a repressão policial e as agressões midiáticas aos protestos; ao 
mesmo tempo, faz isso propondo e reinventando, nos seus mais interessantes poemas, formas poéticas igualmente violentas e disruptivas, plenas de um espírito de transgressão que, diferente daquele praticado pelas forças do Estado (que ignoraram a lei, por exemplo, ao negarem a todos o direito à livre manifestação), quer transformar, subverter a ordem das coisas e não conservá-la.

A primeira face da violência exposta em Vinagre dá conta logo do efeito perverso que a imposição institucional da violência provoca nos próprios sujeitos que a praticam em nome da lei e do direito. No já citado "Lembrete", Adriano Scandolara vai condensar no verso "Havia um homem antes da farda", espécie de refrão que se repete a cada estrofe do poema, a imagem de uma desumanização progressiva, de um apagamento maquinal do humano frente aos dispositivos do poder que corrompe e aliena, criando a ilusão de que braços e pernas são espingardas e cassetetes, e de que o corpo que despedaça não pode, ele também, ser desfeito pela força:

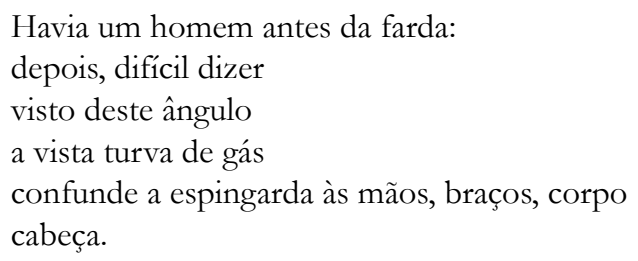

Havia um homem antes da farda:

depois, difícil

o amor à ordem,

ainda que caduque e obrigue

a esquecer como basta

o menor dos impulsos para pedra, faca, estilhaço

rasgar-lhe a garganta.

Havia um homem antes da farda:

depois,

caos, um nada

anterior talvez à farda

à espera que, de ordem, uma palavra

o preencha,

havia um homem -

esse verso impossível de lembrar,

se a hora não é de poemas, falhando a voz,

o coturno abafando a garganta, ódio

trêmulo na fumaça dos detritos. ${ }^{20}$

A estrutura do texto, feito de repetição e elipses, reforça, com seu andamento interrompido, o distanciamento dos agentes de si, de sua condição comum e humana, sugerindo uma ruptura que se aprofunda lenta e seguramente, separando os homens-da-lei dos simples homens, desfazendo a solidariedade,
20. CALIXTO, F. \& TOSTES, P.

Vinagre, 2013, p. 9. 
21. DERRIDA, Jacques. Força de lei, 2007, p. 99. sobretudo corporal, que une (ou deveria unir) a todos e que constrói vínculos (morais, sociais) calcados na identificação de si no outro, do outro em si mesmo. Despido de tudo, esvaziado, o policial, figuração do vazio impessoal do poder, apenas espera "uma ordem, uma palavra" que o venha preencher, numa reencenação paródica do mito judaico da criação: o sopro, a palavra soprada não mais insufla a vida ou o ânimo, mas faz despertar para a destruição. No seu lugar, vem colocar-se um mito decaído, moderno e contraditório por definição: o mito que encena as origens supostamente pacíficas da lei (do direito, do Estado) e naturaliza o exercício da sua força violenta, entendida como única forma de violência aceitável, posto que legal. Elude-se, assim, a fundação violenta da lei, ao mesmo tempo em que se procura mascarar o caráter reativo e conservador da violência do Estado, mobilizada tão somente para garantir os poderes instituídos.

Para uma caracterização breve, mas necessária, da violência policial - e não apenas da polícia brasileira, com seu conhecido histórico de segregação social e autoritarismo, feito de elitismo e aprimorado no longo distanciamento da cidadania produzido pela militarização - é interessante recorrer à reflexão proposta por Jacques Derrida em Força de lei: o fundamento místico da autoridade (2007). Ali, a partir de uma sofisticada leitura do ensaio "Para uma crítica da violência", de Walter Benjamin, o autor vai mostrar que a polícia é, entre as modernas instituições, aquela que vai reunir em si os dois tipos de violência associados ao direito: a violência fundadora e conservadora, isto é, aquela que está na origem histórica da lei e do poder, e aquela que age apenas para resguardá-los. Nesse sentido, a polícia ao mesmo tempo institui a lei, inventando-a ou modificando-a sempre que ela não se mostre clara ou suficiente para garantir a ordem, e também a defende, conjuntamente a todas as demais instituições que têm seu fundamento e garantia na violência do Estado. Sua natureza é, no fundo, indeterminável; seus limites, imprecisos, confundindo-se com o poder que ela mesma quer proteger. Ouço o que diz Derrida sobre essa ausência de limites e seus riscos:

Ela provém igualmente do fato de que a polícia é o Estado, é o espectro do Estado, e que não se pode, rigorosamente, atacá-la sem declarar guerra à ordem da res publica. Pois a polícia já não se contenta, hoje, em aplicar a lei pela força (enforce) e, portanto, em conservá-la; ela a inventa [...]. Ela é a força de lei, ela tem força de lei. ${ }^{21}$

Posta acima de qualquer interpelação crítica decisiva, uma vez que se confunde com o Estado e a própria lei, a polícia vê-se livre para agir como instituição aberrantemente autônoma, ainda que em essência reacionária e subserviente ao poder 
econômico de um modo geral. Sua atuação, num país como o Brasil, torna ainda mais clara as suas aporias e violências. E em nenhum outro momento, na vida pública recente do país, tais questões foram tão visíveis e incômodas quanto nas manifestações de Junho. O episódio do vinagre, é claro, configura-se como exemplo importante, confirmando o alargamento - diríamos mesmo a subversão voluntária - interessado da lei, que não tipificava o delito (por evidente), mas que, naqueles dias de intensa repressão, passou a tipificar, em gesto arbitrário da polícia que chegou a encontrar respaldo posterior em algumas cortes de justiça. Apresentada no poema de Scandolara como sujeitos à parte, distanciados dos demais pelo embrutecimento militarista, os policiais são apanhados em uma trama que os ultrapassa, participando - com ou sem o gozo perverso do poder incontestado, pouco importa - de uma força ambígua por princípio, ao mesmo tempo dentro e fora da lei.

É muito provável que em nenhum outro poema da antologia essa condição ambígua da instituição repressiva tenha sido mais claramente surpreendida do que "A polícia é bela e assassina", do poeta uruguaio Rafael Courtoisie (traduzido por Maykson Souza, outro dos autores de Vinagre). Nele, a ambivalência constitutiva da polícia não se restringe mais (ou apenas) ao campo jurídico. É fundamentalmente estética. A fascinação dos corpos organizados, dos metais resplandecentes, da ordem unida, enfim, se mistura à consciência incontornável dos sentidos da ação policial. O aspecto ignóbil de sua condição dupla, agindo violentamente para fundar e conservar a lei, ganha outra dimensão, na qual o poder que emana dessa instituição ilimitada se transforma em sensação, forma de uma beleza que se impõe. Nela, tudo converge para a destruição, e o belo é terrível: ele faz florescer o mundo, ainda que a colheita que daí devém seja a morte:

A polícia é bonita e assassina, os seus crânios e capacetes, o seu [pau artificial, os gases

lacrimogêneos, seu espírito de corpo, suas algemas, seus carros de [água, o seu modo de

gritar e expressar.

A polícia nos lembra a morte, nos mostra o revólver, a pistola, o [cano do rifle

e murmura:

- Estão vendo a morte?

A morte é como uma uva. Doce e escura. Dá vinho.

E vinagre.

Provem o vinagre.

A morte é como o vinagre.

Estão vendo a polícia que se aproxima com seus carros e escudos, [com suas armas e

catapultas, tão esbelta com suas tropas de assalto em uníssono? [Estão vendo as tropas 
22. CALIXTO, F. \& TOSTES, P. Vinagre, 2013, p. 133.

23. Ibidem, p. 56. especiais, as tropas de elite já chegam, suas filas tão bonitas, [emparelhadas, tão bem

formadas que dão gosto?

$[\ldots]$

É a colheita. Haverá vinho de sangue.

São as uvas da polícia, sim, recém colhidas do quartel, da videira violenta.

A multidão se dispersa. ${ }^{22}$

Outra faceta da violência que aparece em Vinagre tem a ver com a retomada e atualização de um topos poético tradicional, a maldição pública do tirano. No contexto em tela, é o comandante-em-chefe das forças de segurança quem vai figurar no papel do déspota, responsável direto pela brutalidade. A presidente da República é o modelo evidente, mas oculto, de "A história da gerenta", de Ricardo Domeneck, que cria um jogo de contrastes entre a biografia política da presidente (militante da esquerda armada, sobrevivente de torturas e perseguições) e suas ações no presente como administradora -autoritária, para alguns - do país. O governador do Estado de São Paulo, mais do que qualquer outro dirigente político do Brasil contemporâneo, é quem concentrou em si a negatividade da violência e os ritos da revolta social. Seu retrato iria emergir, era de se esperar, no torvelinho dos poemas de Vinagre. O mais incisivo deles é o que foi feito por Dirceu Villa a partir da mobilização de imagens grotescas, segundo as quais o próprio corpo do governador contém os metais terríveis, os instrumentos e símbolos da morte que designam, melhor do que qualquer outra coisa, a presença e as atividades da Polícia Militar:

o governador acorda, bebe chumbo e espalha pólvora no pão.

o governador obtura suas cáries com balas, cobre as vítimas com o sudário piedoso de um sudário todo em sangue.

o governador é um ditador da lei do mais forte, e tem cães de guarda que vestem farda e não respondem à razão ou à justiça. o governador enrola cobras nos microfones, arranca olhos com mãos em luvas de pelica.

o governador quer a ordem dos corpos no chão e protege os eleitores de si mesmos. o governador é um homem bom em casa mesa \& banho. usa um rodo pro dinheiro e faz a ronda do complexo midiático.

o governador tem mãos em todos os bolsos, em todos os coldres, e puxa gatilhos com a língua. o governador sabe de cor 
e salteado as cidades do estado.

ao governador falta um pouco de telhado. ${ }^{23}$

A estratégia aqui é a mesma que vai se repetir em muitos poemas da antologia, e poderia ser descrita com as mesmas palavras que João Camillo Penna usou para pensar a poesia de Armando Freitas Filho. Analisando uma série descontínua de poemas do autor que faz referência a eventos violentos da história recente do país (a tortura infligida a presos políticos da ditadura, a Chacina da Candelária, o assassinato do menino João Hélio, no Rio de Janeiro, a morte da modelo Eliza Samúdio), o ensaísta vai notar que o poeta carioca retira seus textos do "campo da denúncia, inserindo[-os] no campo dos afetos" ${ }^{24}$. Isso significa que a operação poética submete o evento violento, público e históri$\mathrm{co}$, a um regime discursivo que o modifica fundamentalmente, na medida em que vai inseri-lo no universo da subjetividade e da intempestividade, atinente a um tempo interior, não condicionado de modo exclusivo pela sucessão e pela cronologia. Aquilo que os poemas poderiam ter de retórica denuncionista, fundada na repetição esvaziada de certos dados da realidade (prendendo-se, assim, a conteúdos e verdades pré-formados, anteriores ao evento que procuram comunicar) se transforma em mergulho em direção ao outro, ao desconhecido do choque e do trauma que se procura representar. Como já dito, algo desse tratamento do poético se faz presente nos textos reunidos em Vinagre, já que eles se mostraram muito pouco efetivos, como provocação estética, quando expuseram didaticamente o ódio contra a barbárie ou a indignação frente ao colapso da vida pública. Ao contrário, quando apostaram no obscurecimento da linguagem e no abismo da experiência, na desestabilização dos discursos e no tráfico de afetos impronunciáveis, conseguiram, se não compreender plenamente a dinâmica dos protestos e da violência que os cercou, formular as perguntas necessárias e reconhecer os desafios impostos pelo enigma de Junho - o " $\mathrm{X}$ " de valor indecifrável lançado, como um desafio, pelo poema que Carlito Azevedo ${ }^{25}$ publicou na antologia.
24. PENNA, João Camillo. $A$ violência da poesia, 2011, p. 207.

25. Cf. CALIXTO, F. \&

TOSTES, P. Vinagre, 2013, p. 40.

\section{Referências}

AVELAR, Idelber. "O enigma de Junho: os protestos de 2013 e a democracia brasileira". In: Crônicas do estado de exceção. Rio de Janeiro: Azougue, 2014, p. 205-215.

AZEVEDO, Carlito. Monodrama. Rio de Janeiro: 7Letras, 2009.

CALIXTO, Fabiano. Sanguinea. São Paulo: 34, 2007. 
CALIXTO, Fabiano \& TOSTES, Pedro. Vinagre: uma antologia de poetas neobarracos. 2 ed. São Paulo: Edições V de Vândalo. (e-book)

DERRIDA, Jacques. Che cos'è la poesia? Tradução de Osvaldo Silvestre. Coimbra: Angelus Novus, 2003.

DERRIDA, Jacques \& ROUDINESCO, Elizabeth. De que amanhãa.. Diálogos. Tradução de André Telles. Rio de Janeiro: Jorge Zahar, 2004.

DERRIDA, Jacques. Força de lei. O fundamento místico da autoridade. Tradução de Leyla Perrone-Moisés. São Paulo: Martins Fontes, 2007.

FERNANDES, Pádua. Cinco lugares da fúria. São Paulo: Hedra, 2008.

FREITAS, Angélica. Um útero é do tamanho de um punho. São Paulo: CosacNaify, 2012.

FREITAS, Guilherme \& SPREJER, Pedro. "Ação e invenção". O Globo. Rio de Janeiro, 20/07/2013.

HARDT, Michael \& NEGRI, Antonio. "A Multidão contra o Império". In: Império. Tradução de Berilo Vargas. São Paulo: Record, 2005, p. 417-438.

HARVEY, David. Cidades rebeldes: do direito à cidade à revolução urbana. Tradução de Jeferson Camargo. São Paulo: Martins Fontes, 2014.

JUDENSNAIDER, Elena et alii (org.) Vinte centavos: a luta contra o aumento. São Paulo: Veneta, 2013.

LINS, Vera. "O poema em tempos de barbárie". In: O poema em tempos de barbárie e outros ensaios. Rio de Janeiro: EdUERJ, 2013, p. 11-42.

.Poesia e tempos sombrios: alguma poesia hoje".

In:__. Poesia e crítica: uns e outros. Rio de Janeiro: 7Letras, 2005.

MARICATO, Ermínia; HARVEY, David et al. Cidades rebeldes: Passe Livre e as manifestações que tomaram as ruas do Brasil. São Paulo: Boitempo, 2013.

MASSUELA, Amanda. "Vinagre e poesia: entrevista com Fabiano Calixto e Pedro Tostes”. Cult. São Paulo, junho/2013.

MELO, Tarso. Planos de fuga e outros poemas. São Paulo: Cosac Naify, 2005.

NEGRI, Antonio. "Pour une définition ontologique de la multitude". Tradução de François Matheron. Multitudes. vol. 9, Paris. Mai-Jun., 2002. 
NOBRE, Marcos. Choque de Democracia - Razõos da revolta. São Paulo: Companhia das Letras, 2013. (e-book)

PENNA, João Camillo. "A violência da poesia". Alea. vol. 13, Rio de Janeiro: UFRJ, p. 205-226, 2011.

"Poética da vítima". Revista Brasileira. n. 74, Rio de

Janeiro: Academia Brasileira de Letras, p. 87-105, 2013.

REDONDO, Tércio \& RUFINONI, Simone (org.) Caminhos da lírica brasileira contemporânea. São Paulo: Nankin, 2014.

SILVA, Regina Helena Alves (org.) Redes e ruas: dinâmicas dos protestosBR. Belo Horizonte: Autêntica, 2014.

STERZI, Eduardo. Aleijão. Rio de Janeiro: 7Letras, 2009.

. "Terra devastada: persistências de uma imagem".

Remate de Males. vol. 34, Campinas, p. 95-111, 2014.

WEINTRAUB, Fábio. Baque. São Paulo: 34, 2007.

"Poética do desabrigo: imagens do habitar em crise na poesia brasileira contemporânea". In: Caminhos da lírica brasileira contemporânea. São Paulo: Nankin, 2014, p. 135-176.

ZIZEK, Slavoj. "Problemas no paraíso". In: MARICATO, E.; HARVEY, D. et al. Cidades rebeldes: Passe Livre e as manifestações que tomaram as ruas do Brasil. São Paulo: Boitempo, 2013, p. 103-111. 
